招

\section{I. - 般}

熱湯漏斗 (J. R. Caldwell：Ind.\& Eng. Chem., anal. edit., 1935 vol. $7,76$.$) 圖は, 容易に作れる熱$ 湯漏斗である。容器 $\mathrm{A}$ は, 適當の瓶の頂部を切斷し て作る。側管 B は, 硝子或は銅管よりなり，且循環 を迅速にするため徑 8〜10 楀ならしむ。圖は,ブン ゼン登にて加熱してるるも，之は側管に低抗コイル を捲いて，電氣加熱出來る。

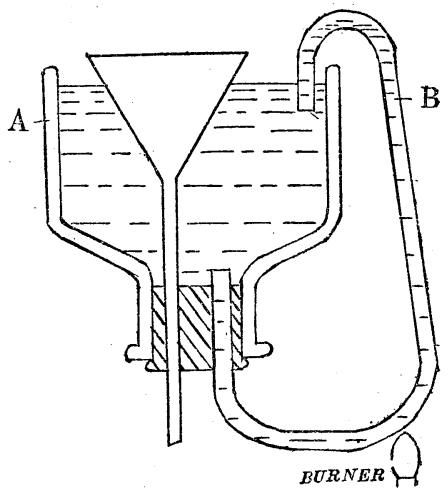

此の方法は，色々の大さに容易に探用し得られる。 $60^{\circ}$ 硝子漏斗々同樣にビエーフネル氏漏斗 (Büchner funnels）にも適用し得る。水に數瓦の監類を落する と, 湯浴の溫度上昇して, 從つて, 滤液は侗沸騰點 に於て保持し得る。

赤 开

可溶情珪酸の定量 (Dr. A. Steopoe, Zement 1934. 23 [52] 759-60) モルタル粉末 $2 g$ を探り之を

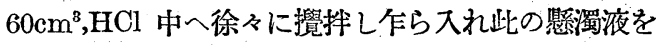
Weiss band filter に体り濾過した酸として $24 \%$ と 1- $N$ を用ひ，倘微粒砂の通過を防ぐ鳥に $1 N-\mathrm{HCl}$ 及び $5 \% \mathrm{NaCl}$ を混合して用ひた，而して此の場合 には滤液は透明となつた。殘殖の洗滌には，冷水或 は熱湯又は $0.8 \%$ 冷 $\mathrm{HCl}$ を用ひ溶解成分は普通の 方法で分析した，此の結果は次表の通りでする。

此の結果より次の事が明かとなる，即ち (a) 始め 濃覧酸を以て處理し次に之を徐々に濾過する Florentin の方法を以てする時は可溶性珪酸の㠜結力:㙨部 分起り從つて其の值他の場合より小である，(b)モル タル粉末の分解に於て 後の濾過の際透明な濾液を得 る急に $(N / 1 \mathrm{HCl}+5 \% \mathrm{NaCl})$ を用ふ，(c) 洗櫒の際
試 料 番 躆

$\mathrm{HCl}$ の處理

洗 滌 方 法

灼熱減量 \%

不溶·解 量 \% $\mathrm{SiO}_{2} \%$

. 溶解成分 $\mathrm{R}_{2} \mathrm{O}_{3} \%$ $\mathrm{CaO} \%$
1

HCl. D. 1.12 普通濾過 (Florention の
方法)
2
3

冷狀 $1 \mathrm{~N}, \mathrm{HCl}$ $\overbrace{\begin{array}{c}\text { 冷 } 0.8 \% \\ \text { HCl洗湺 }\end{array} \text { 熱湯洗湺 }}$

6.99

72.71

3.63

2.21

14.23
冷水丈は溫湯の何れを以て行ふるも滤液は溷濁す，此 の場合 $0.8 \% \mathrm{HCl}$ を洗源夜として用ふれば艮い，此 くして得た殘殖は更にアルカリ溶液で處理する事を

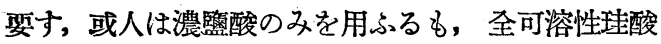
を求め得ると述べてるるが是は正しくない，筆者は 上に得た残殖を更に $\left(5 \% \mathrm{Na}_{2} \mathrm{CO}_{3}+5 \% \mathrm{NaCl}\right)$ 溶液で 處理しアルカリに可溶性珪酸として 全可溶性珠酸中 (14 16\%)存在する事を實驗的に求めた。

\section{洒 确}

長石の分析 (B. Knowles and.J. Redmond, $J$. $\begin{array}{lll}4 & 5 & 6\end{array}$ 冷 $N / 1 \mathrm{HCl}+5 \% \mathrm{NaCl}$

\begin{tabular}{|c|c|c|}
\hline 熱湯洗涤 & 冷水洗涤 & $\begin{array}{l}\text { 椧 } 0.8 \% \\
\text { HCl洗㴚 }\end{array}$ \\
\hline 6.69 & 6.69 & 6.69 \\
\hline 72.92 & 72.69 & 72.67 \\
\hline 3.60 & 3.61 & 3.57 \\
\hline 2.12 & 2.13 & 2.16 \\
\hline 14.23 & 14.30 & 14.27 \\
\hline
\end{tabular}

Amer. Ceram. Soc., 1935, 18 [3], 106〜12) 從來の分 析法はあまりに長時間冢必要とし且つ單に品位の決 定を行ふためには非常な 精密さを必要としない事が 多いので著者は、次の樣な迅速法を呈出した。試料 $0.5 \mathrm{~g}$ を探つて珠酸を定量した時は液の $1 / 5$ を更に $\mathrm{Al}_{2} \mathrm{O}_{3}$ のみを定量する時は $\mathrm{HF}$ と $\mathrm{H}_{2} \mathrm{SO}_{4}$ で珪酸を 除いて全液を $250 \mathrm{cc}$ とし其內 $50 \mathrm{cc}$ を次の實驗に使 用す。液中のアルミニウムは醋酸の存在で 8-hydroxyquinolin で不溶解の: $\mathrm{Al}\left(\mathrm{C}_{9} \mathrm{H}_{6} \mathrm{ON}\right)_{3}$ の淑澱とし Tena glassfilter で濾過してこれを覧酸に溶解し 0.25 
$N$ の potassium bromate-potassium bromide 液を 計算より 2 3 cc の過剩と $20 \%$ の $\mathrm{KI}$ 及び澱粉液 を加へ過剩の臭素を $0.1 \mathrm{~N} \cdot \mathrm{Na}_{2} \mathrm{~S}_{2} \mathrm{O}_{3}$ で滴定し以つて 所要の $0.25 \mathrm{~N} \mathrm{KBr}-\mathrm{KBrO}_{3}$ の量を計算する。 $(0.25 \mathrm{~N}$ $\mathrm{KBr}-\mathrm{KBrO}_{3}$ 液 $1 \mathrm{cc}=0.001062 \mathrm{~g} \mathrm{Al}_{2} \mathrm{O}_{3}$ )。但儿此際注 意すべき事は上記の反應は $\mathrm{Fe}, \mathrm{T}$ 汲 $\mathrm{Zr}$ 等によつ て子起りその誤差は $1 \% \mathrm{Fe}_{2} \mathrm{O}_{3}=0.6 \% \mathrm{Al}_{2} \mathrm{O}_{3}, 1 \%$ $\mathrm{TiO}_{2}=0.4 \% \quad \mathrm{Al}_{2} \mathrm{O}_{3}, 1 \% \quad \mathrm{ZrO}_{2}=0.3 \% \quad \mathrm{Al}_{2} \mathrm{O}_{3}$ に相當 する。其他著者は標淮試藥の製法並に分析法に就て 詳細に說明を與へてるる。次に $\mathrm{N}_{\varepsilon_{2}} \mathrm{O}$ 及 $\mathrm{K}_{2} \mathrm{O}$ の迅 涑定量法として從來の Lawrence Smith の方法と異 つた方法を呈出した。郎ち試料に $\mathrm{HF}$ と $\mathrm{HCl}$ を加 へて蒸發乾固し, 殘渣を水て濕し $0.5 \mathrm{gr}$ 葆酸を加 て加熱し，之を反覆する。冷却し更に $\mathrm{HCl}$ と加熱 後 450cc に稀釋し 8-hydroxyquinoline で處理し, 更に Ba があれば炭酸アムモニウムで洗澱せしめて 濾過し, 液を蒸發乾固加熱して 炭化物等を除く。更 にこ社を少量の $\mathrm{HCl}$ に溶解して $0.1 \mathrm{~g}$ 苳酸アンモ= ウムを加一て焦沸し Ca-oxalate を除き再び液を濃 縮して秤量した白金坩堝中に洗ひ流して蒸發乾固じ アムモニウム鹽等を除くため靜に加熱する。殘洫は 少量の水で濕し $\mathrm{HCl}$ を加へて鹽化物とし更に乾固 して $500^{\circ} \mathrm{C}$ 以下に加熱科量すれば $\mathrm{NaCl}+\mathrm{KCl}$ を得 る。次にこれを 1ce の水に溶し 15ce のZincuranyl acetate を加へ 2 時間放置して Jena glass filter で 手早く罏過しアルュール及エーテルで洗策して科量 すれば $\left(\mathrm{UO}_{2}\right)_{3} \mathrm{ZnNa}\left(\mathrm{CH}_{3} \mathrm{COO}\right)_{9} \cdot 6 \mathrm{H}_{2} \mathrm{O} \times 0.02015 \times$ $100 \div$ 試粼 $=\mathrm{Na}_{2} \mathrm{O}$ であるから美によつて $\mathrm{K}_{2} \mathrm{O}$ を求 むる事が出來る。其他著者は $\mathrm{CaO}, \mathrm{MgO}$ の定量及 び上記分析法の詳細を發表した。 河 島

\section{§ガラス中の酸化第一鐵の定量に就て（新海重} 行·高橋樟宸, 工化, 昭 10，38 [4]，315～18) 著者 は從來知らられて居る方法は AS を含有する确子の 分析に適用し得ない息次の樣な 改皇法を考案した。 郎ちまづ $\mathrm{CO}_{2}$ 氣流中で粉倅した新鮮な試料 $0.5 \mathrm{~g}$ を 白金咕堝中に科量し約 $1 \mathrm{Cec}$ の $\mathrm{HF}$ と $3 \mathrm{cc} \mathrm{H}_{2} \mathrm{SO}_{4}$ と $2 \mathrm{cc} \mathrm{HCl}$ を加へ再び $\mathrm{CO}_{2}$ 氣流中で空氣浴上で 120 $130^{\circ} \mathrm{C}$ に加熱与。此際 $\mathrm{AS}$ は $\mathrm{AS}_{2} \mathrm{O}_{3}+6 \mathrm{HF}=$ $2 \mathrm{ASF}_{3} \uparrow+3 \mathrm{H}_{2} \mathrm{O}$ なる反應によつて揮發するから更 に加熱し $\mathrm{HF}$ 及 $\mathrm{HCl}$ を充分追出 $\mathrm{CO}_{2}$ 氣流中で 常溫まで冷却する。充分冷却しないと結果が非常に 惡い。次に空氣遊離の蒸溜水 $200 \mathrm{ec}$ と粉末䃆酸を多 量扣へ $\mathrm{CO}_{2}$ で茎氣を置換した 500cc のガラ不製ビ
一カー中に手早く埴堝の內容物を洗ひ流し $400 \mathrm{cc}$ 位 まで水を加へて直に $N / 100 . \mathrm{KMnO}_{4}$ で滴定する。 其結果は非常に良好で著者は 各方法による定量の比 較値を揭げて說明した份 HF は Barnebey 氏の主 張する如く $\mathrm{H}_{3} \mathrm{BO}_{3}$ の添加によつて不活性にする事 を得た。

河 島

カオリンル及ぼす酸化亞鉛の影彎（R. Rieke und W. Pasch, Dtsch., Keram., Ges., 1935, 16 [2;] 49－62）著者は各溫度こ於て酸化亞鉛と珪酸琣にカ オリンとの反應を跴究した。(A) $\mathrm{ZnO}$ と $\mathrm{SiO}_{2}$ の反 應一一珠酸亞鉛化合物の生成溫度と其化學組成の決 定夌行ふため先つ試料として为熱した純 $\mathrm{ZnO}$ と微 粉した Hohenbocker の珪砂 (99.85\%) を $1 \mathrm{ZnO:}$ $1 \mathrm{SiO}_{2}, 2: 1,3: 1$ の各比率に調合し $50 \mathrm{~kg} / \mathrm{cm}^{2}$ で圓杜 狀に成形し $800,900,1000,1100,1200$,及び $1250^{\circ} \mathrm{C}$ の各

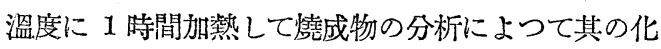
合狀態を調べた。郎ち試料 $2 \mathrm{gr}$ Muspratt 液(320 gr $\mathrm{NH}_{4} \mathrm{Cl}, 640 \mathrm{cc} \mathrm{NH}_{4} \mathrm{OH}$ (sp. G. 0.9), 1040cc 蒸溜

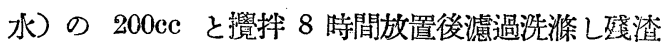
は更に $200 \mathrm{cc}$ の液で湯祭上で 2 時間應々攪找しつ >加熱し濾過洗滌灼熱後秤量す。二滤液を合して亞 鉛を定量し斯くして溶解した遊離酸化亞鉛を求むる 事が出來る。殘查中には $\mathrm{ZnO}$ は珪酸覧として存在 し其他遊離珠酸を含んでるるが著者は Conc $\mathrm{HCl}$ で これを分解し更に曹達溶液で處理し 硅酸を定量して 珄酸亞鉆の化合比率を求めた。實驗結果によると $\mathrm{ZnO}$ と $\mathrm{SiO}_{2}$ の化合は $1000^{\circ} \mathrm{C}$ て始まり次第に溫度 の上昇と共に化合が進んだが 理諭值の半分にも到し 得なかつそ。生成物は何れる orthosilicate 郎ち 2 $\mathrm{ZnO}: 1 \mathrm{SiO}_{2}$ の比率を示したが理酸が多い、訊料程其生 成量妿大きかつた。(B) $\mathrm{ZnO}$ と Kaolinit の反應一 著者は嚾料として $1 \mathrm{ZnO}: 1 \mathrm{Kaolin}, 2: 1,5: 1$ 及び 6:1 の割合に調合し $700,900,1100,1200^{\circ} \mathrm{C}$ の各溫 度に加蓺し同樣に蔩驗を行つた。其結果によるを $706^{\circ} \mathrm{C}$ では何等反應は認められず $900^{\circ} \mathrm{C}$ で極く僅か 反應したが加熱時間の增加と更に溫度の上昇につれ 著しく反應が速進した。 区應物は何れる Zinkorthosilicate そ Zinkspinell $\left(\mathrm{ZnO} \cdot \mathrm{Al}_{2} \mathrm{O}_{3}\right)$ であたが 結果 spinell は silicate よりも化合し易く大部分の $\mathrm{Al}_{2} \mathrm{O}_{3}$ は spinell として化合し特に 1:1 のものでは 珪酸亞鉛の量は非常に少ない事を知つた。從つて珪 酸は遊雜の狀態となり熱膨脹昍線によつて 明にクリ ストバライトの港常瞦脹を認めた。著者は其他㰸化 
溫度を測定したが本系の耐火度は $47 \% \mathrm{ZnO}, 24.3 \mathrm{Al}_{2}$ $\mathrm{O}_{3}, 28.7 \mathrm{SiO}_{2}\left(2.4 \mathrm{ZnO}: 1 \mathrm{Al}_{2} \mathrm{O}_{3}: 2 \mathrm{SiO}_{2}\right) 1320^{\circ} \mathrm{C}$ て最低

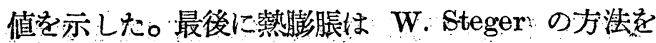
用ひて測定し試料は $0.68 \mathrm{ZnO}_{\mathrm{nO}}$ :1Kaolin; $1: 1.47: 1$ の 3 種で徑 $3 \mathrm{~mm}$, 長 $6 \mathrm{~cm}$ の棒狀とし 1150,1200 , $1250 ， 1300 ， 1350$ 及 $1400^{\circ} \mathrm{C}$ に各 2 時閒燒成した。 $1150^{\circ} \mathrm{C}$ に燒成したものはクリストバライトの異常膨 脹は認め得ないが $1200 〜 1300^{\circ} \mathrm{C}$ に褺いたものは著 しく其變化を示した。これは以上生成物が三成分の 化合物に非ずして Zinc Spinel とクリストバライト から成る事を立證したもので其他著者は顥徽鏡觀察 に就ても種々說明を與へた。 河 島

\section{可塑性を有する耐火粘度に及ぼす熔融アルミ} ナ及嗍酸の影響 (G. Moore and R. Hursh, Bull. Amer. Ceram. Soc., 1935, 14 [3], 106〜12) 著者は 3 種の異つた耐化物の結合劑用粘度に少量の熔融 $\mathrm{Al}_{2} \mathrm{O}_{3}$ 及 $\mathrm{B}_{2} \mathrm{O}_{3}$ を加一各物理的諸性質を湘定した。 粘度は 30 メッシニを大部分通過せしめ $\mathrm{Al}_{2} \mathrm{O}_{3} 5$ 及 $15 \%, \mathrm{~B}_{2} \mathrm{O}_{3} 2$ 及 $5 \%$ を添加成形し SK14 に 24 時間 燒成した。結論は $\mathrm{B}_{2} \mathrm{O}_{3} 2 \%$ 含有したものはスポー リングに强く收縮を減じ 更に熱膨脹を減少したが珠 酸の多い粘度或は不純物の多いものには收縮を減じ た他は岕まり效果がなかつた。熔融アルミナ $15 \%$ 添 加したものは荷重下の耐火度を增しスポーリングに も强かつたが或る粘度では反つて反對の結果を示し 又少量の愹融アルミナを加へても熱膨脹には變化が 無かつた。要するに少量の $\mathrm{B}_{2} \mathrm{O}_{3}$ を加へた時の樣に 耐火物中に生成する硝子が相當重要な意義を有する ものである。

河 島

\section{クロマイト並にクロムスピネルの熱膨脹 (J.} Chesters and C. Parmelee, J. Amer. Ceram. Soc., 1935, 18 [3]，94 -100) 著者は Cuban chromite brick, Electrically fused magnesia 及 Austrian magnesite brick 其他純粹な $\mathrm{Cr}_{2} \mathrm{O}_{3}, \mathrm{Al}_{2} \mathrm{O}_{3}$ 等の諸 原料を用ひた。試粼は高さ 1.5 时, 直受 0.88 时の 圓杜狀に成形し “reaction-expansion” 裝置（前報 本誌，1934，17 [3]，50〜59）によつてモりブデン 担抗濾を用ひ精密な Ames dial で 1/10,000 时恋で 測定した。(1) $\mathrm{MgO}+\mathrm{Al}_{2} \mathrm{O}_{3}$ (2) $\mathrm{MgO}+\mathrm{Cr}_{2} \mathrm{O}_{3}$ (3) $\mathrm{MgO}+\mathrm{Al}_{2} \mathrm{O}_{3}+\mathrm{Cr}_{2} \mathrm{O}_{3}$ (2:1:1) (4) Unfired Cuban Chromite (5) Cuban Chromite + Austrian Magnesite (6) Cuban Chromite $+\mathrm{Al}_{2} \mathrm{O}_{3}$ 等の各混合物に 就てそのま〉實驗を行ひ最後に 1400 或 $1500^{\circ} \mathrm{C} に$
2 時間保ち燒成時間と膨脹の狀態を測定した。，實驗 の結果はマグネシアとアルミナ或は酸化》口ふを混 合した場合 $1500^{\circ} \mathrm{C}$ でのスピネル生成速度は $2 \% の$ 硼酸の添加によつて著しく高められ 前者の場合では 生成溫度を添加しないるより $200^{\circ} \mathrm{C}$ 位低くする。 $2 \mathrm{MgO}: \mathrm{Al}_{2} \mathrm{O}_{3}: \mathrm{Cr}_{2} \mathrm{O}_{3}$ ，の割合に混合した象のは $1356^{\circ} \mathrm{C}$ で著しく反應を初めその反應生成物は X線淮察によ ると Magnesium chromite 及び X線的に Ohromite と aluminate 中間に位する spinel との混合物であ ると著者は云つてるる。未燒成の Cuban chromite の試料は $1300^{\circ} \mathrm{C}$ で收縮を初め $1500^{\circ} \mathrm{C} 2 \mathrm{hrs}$ で 2,2 \%を示した。次に Austrian magnesite 20\% 或は熔 融マグネシア $10 \%$ を加へるを 其收縮を防ぎ得るの は液體部が $\mathrm{MgO}$ と反應して forsterite と覺しきも のを生成するためである事を發見した。叉chromite の $20 \%$ を熔融アルミナで置換する事が出來た。

河 島

\section{墨業製品の所謂高溫荷重能力に閣する一考察} （近藤清治·鈴木信一，工化，昭 10，38.[4];309）本 報は预報として發表されたものであるが荷重下で軟 化する宰業製品の軟化溫度を Clasius-clapayron か ら誘導した $t=C_{e}^{-k P} t$ 軟化點, $C$ 耐火度, $P$ 荷重 の式力適用し得るか否かに就て 文衕に見る數值と本 式による計算値の比較を述べ更に高溫荷重能力と實 際的の意義に就ての考察を與へた。河 島

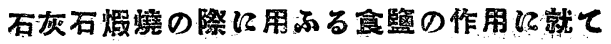

(野田稻吉，工化，昭 10，38 [4]，326〜36)，第-2 報 には石灰中の鐵分に及济す食監の化學作用に就て炭 酸瓦斯流中で食監を含鐵石灰に直接混合した場合と 食䝂蒸氣を作用せしめた時との 反應並に炭素或は一 酸化炭素の存在で行つた 同樣な反應に就て 研 究 し た。其結果によると還元氣流中で $1000^{\circ} \mathrm{C}$ に熱寸る 時鐵分は監化鐵となつて著しく消失し更に同氣流中 で含鐵炭酸カルシウム $\left(\mathrm{Fe}_{2} \mathrm{O}_{3} 0.145 \%\right)$ を烺燒するを 鐵分は 金屬鐵或は低級酸化物になつて試料の色が㱠 んど白色に近くなる事を認めた。第 3 報では酸化鐵

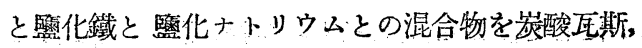
等素, 一酸化炭素及 空氣流中に加熱して反鷹狀況を 觀察 ᄂ $\mathrm{Fe}_{2} \mathrm{O}_{3}+6 \mathrm{NaCl}=\mathrm{Fe}_{2} \mathrm{Cl}_{6}+3 \mathrm{Na}_{2} \mathrm{O}$ ， の應恒數 , $\Delta \mathrm{F}^{\circ}$ 算出 L更に $\mathrm{Fe}_{2} \mathrm{O}_{3}+3 \mathrm{CaCl}_{2}=\mathrm{Fe}_{2} \mathrm{Cl}_{6}+3 \mathrm{CaO}$

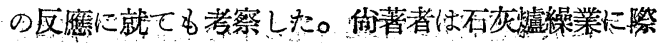

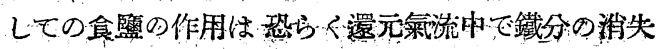
を促進し 且不灰の外觀を善くするに役立のすのと推 
察した。

$\mathrm{Na}_{2} \mathbf{O}-\mathrm{B}_{2} \mathrm{O}_{3}$ 系 1 $\sim 4$ 報 (S. Cole and N. Taylor, J. Amer. Ce am. Soc., 1935, 18 [2]. [3])

埭孔性斷熱體の熱傳導の理論 (H. Russell, $J$. Ainer. Ceram. Soc., 1935, 18 [1], 1 6)

\section{II. 燃料及案爐}

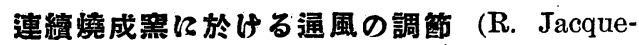
min, Ceramique, 1934, 37 [554], 111-13) 箘業用連 續筧の最大能力を發揮せしむるための パイロメータ 一, $\mathrm{CO}_{2}$ メーター及通風計使用法を詳細說明せり。 䫅 本

白色唡器の電熱燋成 (H. Masukowitz, Elektrowärme. 1934, 4 [11], 245-53) 電兲燒成㯌道窝の瓦 斯或は石炭焚に比し㒔越せる點を 特に白磁燒成に就 き諭議せるるのにして電熱㯌道空は (1) 燒成時間の 短縮，(2)取披の簡易化による賃銀の低下，(3) 墨容 積の縮小による熱エネルギーの低減並に 嘿容積に對 する燒上唱容積比率の增大，（4）燒上品の色に惡影 響を及ぼす如き 有害瓦斯發生せざること等他式の鉒 に比し甚だ有利なり。 $1500^{\circ} \mathrm{C}$ まで得らる〉電熱式㯌

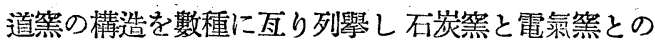
操作を比較せり。長さ $48 \mathrm{~m}$, 最高溫度 $1300^{\circ} \mathrm{C}$ を有 する單線及梅線各㯌道窵の熱平衡を 提示せり。これ

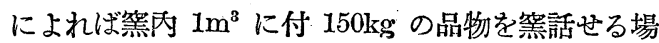
合其電力使用量は燒上品 1 吨頓に付單軌道式にて2000 $\mathrm{kw}-\mathrm{hr}$, 複軌道式にて $730 \mathrm{kw}-\mathrm{hr}$., 磁器焅出量は夫 々 24 時間に 2000 及 $4000 \mathrm{~kg}$ なり。叉 1 年間を平 均せる嶵上經費は減價消却，修理費及給料を含め複 式黨にて燒上品 1 吨㑯に付 2.50 マークなり。

梗 本

小型輪嘿 (Vladimir E!iás, Staviro, 1934, p. 191) 6 室を有する牛連續式平地箁に中央隔壁を設けて 12

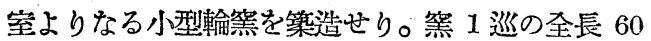
$\mathrm{m}$, 筧室の幅 $1.2 \mathrm{~m}$ にして 12 の各室は夫々 3800 本 の䗲瓦を篦詰するに足る。燒成速度は最初 1 畫夜 5 m にして後 $10 \mathrm{~m}$ となせりり。然料炭消費量料瓦 1000 本につき $250 \mathrm{~kg}$ とす。

榎 本

墨業に於省熱的研究 (B.Helan, Bull. Masaryk Acad. Labor, 1934, No. 43, p. 20) チェュスロバー キアに於る燃料及熱工學研究の中心は 同國燃料經濟 研究所にして䇺業學會熱工學委員會はよく研究所と 連絡を保ち筀業黨爐の改良淮步に功獻するところ頗
る多し。最近同委員會の墢表したる 研究は普通使用 せらる\輪筀の中構造並に實際成績優良と認めらる 〉數基に付熱工學的調查をなし墨業品燒成に 要する 熱量計算式を作製したるものなり。輪筧に於て $100 \mathrm{~kg}$ の湅瓦燒成に要する熱量は次式により算出せらる。 郎ち $Q_{\mathrm{kcal}}=425.2 m-290 n-\imath(639-t)-(24.100 / \mathrm{q} 0 \mathrm{H})$ SP 式中 $m=$ 㤹瓦素地の含有する $\mathrm{CaCO}_{3}(\%), n=$ 同 $\mathrm{MgCO}_{3}(\%), v=$ 同全水量 $(\%), t=$ 穼詰直後の枯

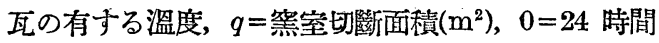
に於る火の進み $(\mathrm{m}), \mathrm{H}=$ 﨨內容積 $1 \mathrm{~m}^{8}$ に積まる 稞瓦の重量 $(\mathrm{kg}), \mathrm{S}=$ 筧室內熱輻射面積 $\left(\mathrm{m}^{2}\right), \mathrm{P}=$ 其 他の損失熱量（一般には 200 300kcal を使用す)。 次にこの Q の值より全燃料消費量は次式により算出 せらる。 $\mathrm{Q}_{\mathrm{c}}=\mathrm{Q} \times 100 /(100-k-n-p)$ 式中 $k=$ 煙突 に持去らる 熱損失 $(\%), n=$ 不完全燃燒の結果失は る上熱量(\%), $p=$ 灰中に殘る熱(\%)。榎

煉瓦工場用薪材燃料 (O. Skála, Stavivo, 1933, p. 384)チエコスロバーキヤ國內ある地方の蟠瓦工場 に於ては燃料として盛んに薪材を使用す。薪材より 生ずる灰は肥料となす。樫灰は $\mathrm{K}_{2} \mathrm{O}$ 含有量最大に して $25 \sim 35 \%$ ，梅これに次ぎ $20 \sim 30 \%$ ，又 $\mathrm{P}_{2} \mathrm{O}_{5}$ 含 有量は樫 12〜20, 梅 8〜14\%なり。㮌 本

磁器燒成墨に於る泥宸の䗳偾 (P, Pusak, $K e-$ ram. i Steklo, 1934, 10 [10], 17 19) 磁器空燃料と して泥炭を使用することの可能なることを論荼し實 驗結果を表示せり。 梖 本

マグネサイトクリンカー等造用高溫度工業爐 (E. Mamour, Ceramique, 1934, 37 [558], 215 16) 熔融マグネサイト製造用瓦斯䇺 2 種に 付詳述せり。

榎本

瓦斯燃料 (R. D. Verre \& Silicates Ind., 1934, $5[19], 362-66 ;[20], 379 \sim 83)$ 工業燃料瓦斯及重油 並に其燃燒に關して研究せり。燃料の化學組成，發 熱量計算法, $1 \mathrm{~m}^{3}$ の瓦斯燃料を燃燒せしむるに要す る宾氣量, 燃燒によりて得らる入理論上の溫度, 瓦 斯密度, 燃堯生成物の容積, 其中の水蒸氣量及化學 成分等を表示したり。

榎 本

マッフル弿による蛄成 (A. J. Blume, Bull. Amer. Ceram. Soc., 1935, 14[1], 20-21.)

不連續黑による蟯成 (A. J. Blume, Bull. Amer. Ceram. Soc., 1935, 14[1], 19-20.)

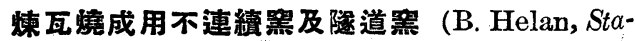
vivo, 1934, p. 154.) 


\section{III. 陶 磁 器}

磁器㮃の微搆造に就て第2 報（近藤清治, 湯大 緰, 東京工業大學學報, 昭 10.3,4 [3],217 25)．要 旨。(1) 釉式の $\mathrm{KNaO}$ 及び $\mathrm{CaO}$ を $0.0 \sim 1.0, \mathrm{SiO}_{2}$ を 2〜12 に變へ, $\mathrm{Al}_{2} \mathrm{O}_{3}$ を $0.3+\mathrm{SiO}_{2} / 12$ にしたもの 郎ち $\left.\begin{array}{l}0.0 \sim 1.0 \mathrm{KNaO} \\ 1.0 \sim 0.0 \mathrm{CaO}\end{array}\right\} 0.467 \sim 1.3 \mathrm{Al}_{2} \mathrm{O}_{3} \cdot 2 \sim 12 \mathrm{SiO}_{2}$ なる 磁器釉 51 種定素燒試驗板に施し，之を瓦斯、。フ 儿試驗䈇で SK8, 10,12,14 及び 16 並に石炭焚工業 筀で SK $171 / 2$ に本燒して嬏の微構造を觀測した。其 結果は C. L. Thompson が猍い範園に就て矽究した ものと似てるる。（2）アルミナは結晶の主成成分で 岕り且釉の粘度を高めて結晶の 成長を阻止するが故 に㠦消嬏の生成に重大なる關係がある。(3) 多數の 光澤釉には不溶解石英粒と灰長石又はムライトの痕 跡を認めた。從つて嬏を釉硝子とは多くの場合一致 しない筈である。(4):アルミナ，珪酸及び石灰の多 い釉は低溫度では熔けず，高溫度では結晶を生じ易 い。（5）燒成の溫度が高く時間が長い程結晶の量及 び大さが堵し發達が善くなる。(6) 正長石の結晶を 見なかつた。(7) 失透は素地の附近, 試驗板の周邊 及び氣泡の周圍に起り易い。

内 田

雲母.基礎とする磁器化材料 (Soc. Anon. des Manuf. des Glaces et Prod. Chim. de St.Gobain, Chauny et Cirey, 英國特許, 418488, 1934) 細新せる黑雲母叉は金雲母と可熔性フラックス（F） との混合物を F の軟化點迄加熱し， $400^{\circ}$ に加熱せ る金屬型にプレスして䅞子を成形する。F は $\mathrm{Na}_{3} \mathrm{AlF}_{6}$ $10 \%, \mathrm{SiO}_{2} 10 \%, \mathrm{~Pb}_{3} \mathrm{O}_{4} 30 \%$, 長石 $15 \%, \mathrm{H}_{3} \mathrm{BO}_{3}$ $35 \%$ をフッットとしたもので其軟化點は $420^{\circ}$ であ る。

内田

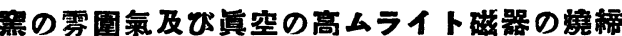
度に及ぼす影蓄（A. M. Hossenlopp \& R. Russel, Ceram Ind., 1935, 24 [3], 162)高ムライト磁器 の燒成中に於ける各㮔の熹の 雾圍氣の見掛比重, 燒 締り溫度範圍に及ぼす影響を 決定する研究をした。 各種の雲圍氣狀態は嚜に $\mathrm{O}_{2}, \mathrm{~N}_{2}$ 及び $\mathrm{CO}_{2}$ を入れ又 部分犋空を用ひて作つた。磁器は白金線抵抗電氣爐 で燒成した。部分筫空を作る爲には爐を鋼製鼓の中 に置て氣密にした。鼓を水銀柱 $0.3^{\prime \prime}$ の絕對壓力に迄 真空にするのに約 5 分間を 要してるる。 3 個のレオ スタっトを使用して最高溫度帶に於て溫度を+ $-20 \mathrm{C}$ に保持した。用ひた雾圍氣は（1）全燒成行程を通
じて $\mathrm{O}_{2}$ ，（2） $1000^{\circ} \mathrm{C}$ 汽 $\mathrm{O}_{2}$ を用ひ， $\mathrm{N}_{2}$ を用ひ燒成 を完了し，(3) $1000^{\circ} \mathrm{C}$ 迄 $\mathrm{O}_{2}$ を用ひ，次に $\mathrm{CO}_{2}$ を 用ひて燒成を完了し，(4) $1000^{\circ} \mathrm{C}$ 迄 $\mathrm{O}_{2}$ を用ひ，部 分斯空で燒成を完了してるる。此實驗の結果次の一 般的傾向が示されてるる。郎ち (a) 燒締りの間に中 性の雲圍氣を存在せしめると酸化性のるのに對比し て見掛此重を減じ，燒締り溫度を低下し，燒締溫度 範圍を短かくする。(b) 燒締りの間に於て部分自空 を用ひると，酸化雾圍氣の時に對比して見掛比重を 減少し，燒締り溫度を低下し，燒楴り溫度範圍を長 くする。

内田

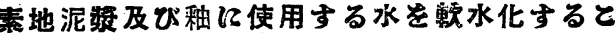

之 (John H. Grady, Ceram. Ind., 1935, 24[3], 174 ～80)釉及び粘土泥漿の裴造に於て最も重要なる因子 の一つは粘度の調節である。粘土泥漿又は釉を貯藏 して置いた時の其硬さ及で粘度の 變化は既に觀察さ れてるることであるが，是は極めて重要なことであ つて，是を用ひた時の均一性及び 㲘濁體の安定性を 增大するからである。著者は多くの機會に於て各種 の水を素地及び勫に用ひる必要を感じたが，是等の 水は硬度に非常な變化があつて，炭酸石灰として 100 萬分に對して 20 分から $10 c 0$ 分迄變化があつ た。 4 種の釉郎ち（1）生釉, 少量粘土，(2) 生嬏, 多量の粘土，(3) フリット釉, 少量の粘土，(4) > リット嬏, 多量の粘土に就て硬度 100 万分に付 20 〜 1000 分なる水を用ひて研究を行つたが，凡ての他 の因子が一定ならば，釉の硬さ及び粘度は鑛物含有 量の多き水の使用に依つて非常なる影響を受け，一 般に釉を 24〜72 時間の範園で浮游させた。此浮游 は工業に於ては最も厄介なことで，釉の原料を緜濁 させる篇に電解質を加へる必要が起つて來る。乍然, 或るアルカリ監類の使用は，其量の僅かの墦加又は 減少も過度の浮游を起したり又は不十分な浮游しか 起さなかつたりするので好ましくない。釉及び素地 用水から誘導された或る浮游性イオン郎ち, $\mathrm{Mg}^{++}$, $\mathrm{Ca}^{++}$及び $\mathrm{SO}_{4}^{--}$の存立に体つて素地又は租が浮 游することは既に Hall に估つて論述されてるるこ とである。依つて素地又は嬏に用ひる水は硬水なら ば軟水化して使用せねばならぬ。是は化學的處理に 体つて篇し得るのである。水の硬度の性質は殆ど常 に水に溶けてるる $\mathrm{Ca}$ 及び $\mathrm{Mg}$ の監類に依る。炭酸 石灰及び炭酸苦土は水に不溶性ではあるが， $\mathrm{CO}_{2}$ にに 体つて溶かされるもので可溶性の $\mathrm{Ca}$ 及び $\mathrm{Mg}$ の重 
炭酸䜿を作ること次式の如くである。毁ち $\mathrm{CaCO}_{3}+$ $\mathrm{CO}_{2}+\mathrm{H}_{2} \mathrm{O} \rightarrow \mathrm{Ca}\left(\mathrm{HCO}_{3}\right)_{20}$ そして是等の重炭酸監は水 酸化石灰の使用に体つて $\mathrm{CO}_{2}$ を驅逐して又不溶性の 炭酸籃となし得ること亦次の如くである。郎ち $\mathrm{Ca}$ $\left(\mathrm{HCO}_{3}\right)_{2}+\mathrm{Ca}(\mathrm{OH})_{2} \rightarrow 2 \mathrm{CaCO}_{3}+2 \mathrm{H}_{2} \mathrm{O}_{\circ} \quad \mathrm{CaCO}_{3}$ は沈 澱するから除去し得られ斯くて水は僌水化されたの でむる。但し重炭酸苦土の場合には用ひる 水酸化石 灰の量は重炭酸石灰の場合の 2 倍量を使用すべきで 是は次式から明らかである。郎ち, $\mathrm{Mg}\left(\mathrm{HCO}_{3}\right)_{2}+2 \mathrm{Ca}$

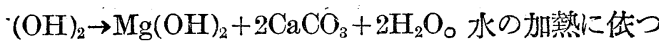
て石灰及び苦土の重炭酸䜿を除去することが行はれ てるるが此硬水は一畤硬水と稱へてるる。是に對し て石灰及び苦土の他の化合物郎ち硫酸䜿，監化物及 び确酸監を含有する水を永久硬水と呼び，是等の物 質は曹達灰を用ひて水から除去すること次式の如く である。郎お, $\mathrm{CaSO}_{4}+\mathrm{Na}_{2} \mathrm{CO}_{3} \rightarrow \mathrm{CaCO}_{3}+\mathrm{Na}_{2} \mathrm{SO}_{4}$ 。 不溶性の炭酸石知が沘測し無需の 硫酸曹達力゙溶液中 に殘留してるる。 $\mathrm{MgSO}_{4}$ \&同樣の式に從つて水から

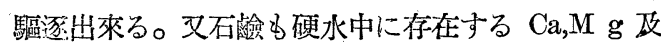
び Fe の化合物と反應し是等の鑛物の石羷をつくる こと次式の示寸如くである。郎ち $\mathrm{CaSO}_{4}+2 \mathrm{Na}\left(\mathrm{C}_{18}\right.$ $\left.\mathrm{H}_{35} \mathrm{O}_{2}\right) \rightarrow \mathrm{Na}_{2} \mathrm{SO}_{4}+\mathrm{Ca}\left(\mathrm{C}_{18} \mathrm{H}_{35} \mathrm{O}_{2}\right)_{\text {。 }}$ 次に濁水の清浮法 に就ては僅か濁つてるる水ならば夫はコロイド質物 に依るので淲降劑と結合や゙しめればよい。此化學的 結合は沅降劑が解離しでイオン化することに依つて

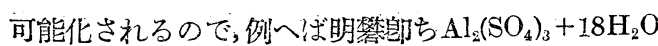
は解離して Al+++ イオン及び $\mathrm{SO}_{4}$-ーーイオントな る。粘土及び泥は一に荷電してるるから Al イオン と結合し化合物をつくる。同時に $\mathrm{Al}(\mathrm{OH})_{3}$ が出來, 機 械的に㲘濁粒を抑留する。

内田

磞性血の人工乾燥 (A. I. Aogustinik \& S. D. Kashtelgan, Keram. i. Steklo, 1934, 10 [11], 23 9）磁性血の乾燥條件を決定する實驗を行つてるる。 結果を表で示してあるが，（1）皿住乾燥窒の空氣を 人工的に濕すことでなく，皿を石高型に入れて乾燥 するとよい。（2）乾燥室の空氣の溫度の最高は乾燥 の初期より終期迄 $90^{\circ} \mathrm{C}$ である。(3) $50^{\circ} \mathrm{C}$ 迄型を预 熱することほ乾燥し燒成した典の性質に對しても丈 乾燥速度に對しても影響を虽らさない。（4）空氣を 人工的に流動せしめれば乾燥は速められる。

内田

蛄成中に於ける被小磁器製品の變形 (IIYa：

Yurchäk, Keram. i. Steklo, 1934, 10 [10], 6 10)
磁器調合物の精製法の變形に對する影響; 磁性皿の 變形に及ぼす成形法の影響, 磁器の燒成法に就て詳 述してるる。

内.”田

摆度の急變に對する抵抗性大好る磁器 (P. de Groote, Ceramique,1934, 37 [558], 209〜15) 錫 又はアンチモニーの如き金跔の熔融體を 磁性坩堝に 添加することに体つて溫度の急速變化を起し， 此狀 態に對する最る抵抗性大なる 磁器ではアルカリ分の 比は $0.1 \mathrm{CaO}, 0.5 \mathrm{MgO}, 0.4 \mathrm{~K}_{2} \mathrm{Na}_{2} \mathrm{O}$ なることを見出

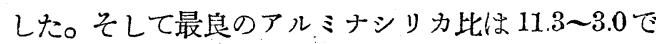
あつた。

内田

ウェッデウッドアンドクキーンスウェヤ（Laura Lorenson, Arts \& Dec., 1934, 41[6], 58 9) クサ ーンスウェヤ(Queen's ware) は 1765 年にQueen Charlotte の作つたものであるが，ウェッ゙ウッド (Wedgwooł) は是を淮步させて精磁器を粗陶器との 間の溝に對する橋渡しをした。此製品はクリームの 陶器であつて，常春滕，檻，バスケット，竹等の簡 單なデザインを持つてるる。 内田

陶器素地 (I. E. Sproat, 米國特許, 1984163, 1934) 牛磁器化陶器素地は粘土及び少くとも $10 \%$ の パイロフィライトより成る混合物から作られる。 内田

檤空容器中に電流を通ずる方法 (H. Handreck, Z. tech. Physik, 1934, 15 [11], 494 -6) 各種の 陶磁器素地(膨脤係數 $2.5 \sim 9.0 \times 16^{-6}$ ) は确子を用ひ て金屬に於けるハンダと同㨾方法で一所に愹融する ことが出來る。此方法の最も重要な 點は硝子の膨脹 が陶磁器の夫よりも小なることである。硝子を中間 物として金屬を陶磁器に結合するのである。金屬を 篣業原料より作れる棒に被覆し次に此棒を确子の薄 層を用ひて陶磁性板に接合すればよい。金屬被覆は 電流を通じ，棒は要求される强度を興へる。 内田。

嬏の重裂と制離 ( $\mathrm{J}$. W. Mellor, Trans. Cer. Soc., 1935, XLIV [1], 1 112) 內容。(1)緒論，(2) 素地之租の熱膨脹保數一是等の 係數に對する溫度の 影響; 是等の係數の大さの相違に体つで起る歪の性 質; 熱的歪に依る素地の機械的强度の減少，(3) 臨 裂の及び剩離の擬態一外觀上鼠裂の樣に見える虽

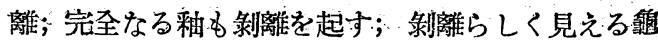
裂，(4) 釉の彈性或は粘靱性一釉の 彈性に及沃す䧽 の組成の變化の影響, (5) 龜裂及び剝離の機構一翻 


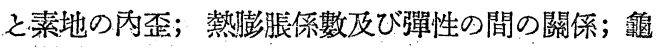

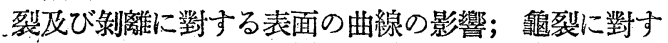
る橎の厚さの變化の影響, (6) 鄱の湑結; 釉の粘度 一勫は徐々の軟化點を有する凝結した液體である; 冷却しつ১ある橎は三種の狀態郎ら (a)流動性夜體, （b）粘歎性液體，（c）脆弱なる固體を通過する; 婇 の物理的性質に對する溫度の影響; 釉の粘度に對す る其組成の影響; 溫度の上昇に伴ふ素地の徐々の顽 化；素地と釉の內歪に及ぼす渴結溫度の影響；釉の

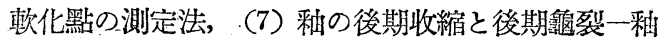

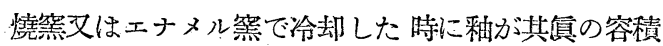
になつて行くのに非常に時間かかるる；翻は一度熱 せられたるのであるから，非常に時日を經過して初 めて其其の容積になる; 租が非常に時日を經てるる 間に收縮(後期)することが勫燒等から出た時及完全 に見えた鄱に龜裂を現はして來るのである，郎ち後

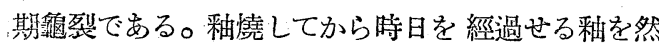

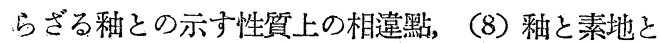
の交涉一嬏燒中に於ける嬏に体る素地の溶解；嬏中 に於ける素地の溶液の結晶; 婇中に於ける素地の溶 解は釉と素地との間に中間免を形成する; 完全なる 翻の䉆には此中間帶を十分發達させることが必要で まる; 磁器化素地; 一四燒成器物の龜裂; 釉を厚く 施した方が薄い時よりも畠裂の可能性が大である; 下繪具，(9)龜裂に對する橎の重量（オンス/パイン ト)の影響一厚くかつつた釉と薄くかつつた釉の龜 裂; オンス/パイントの大なるものは龜裂の傾向が大 きい，(10)鼣裂に對寸る冷却速度又は再加熱の影響 一急冷に体る過大なる脆弱性；急冷釉に於ける非常 なる歪 (婇燒刃はエナメル塞); 器物をエナメル弿で 加熱した時の嬏と素地の不等膨脹に 依つて起る歪; 硝子交び橎に於げる歪の說明, 冷却歪の測定, 硝子 及び婇に於ける歪の解ける 速さ; マッフル喜で加熱

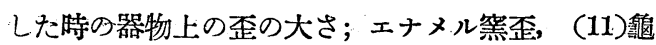
裂に對する素地の氣孔率の影響; 氣孔率に對する焅 成法の影響，熱膨脹係數に對する氣孔率の影響，不 磁器化素地に於ては硬燒叉は長時燒成は 鼠裂の傾向 を減ずるが，磁器では是と反對である，(12)酯裂に 對する素地の組織の影響一龜裂に對する:製造法の影 響・(鑄込泥漿の重量; フィルタープレスするに用ひ る泥獎の重量; 粉塵壓控成形に体る器物; 䡙轓成形

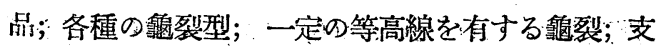

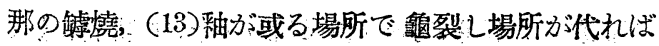

澠裂せざることある理由一釉及び 素地の不均質性； 妨げられたる反應；熔融長石中に於ける石英の塔解 度; 嬏の後期行篇に對する 各種の方法に於兴翻の 調合法の影響，(14)䰠裂刎落に對する，素地中の理 酸の割合と細度との變化の 影響一素地中にプリント の割合を多くせば㑌裂を防ぐ；細度小ならば鳰裂をを 助け；粉稺し過ぎれば制離学助けて，(15)フリント

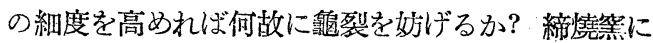
於て; フリントと他の素地成分との間の反應は粒子 の表面に於てのみ起り得る；フリントの細度を高め れば接觸面を著しく拱大する，故にフリントの細宸 の增大はフリントを㙩量することに等しくなる， (16)フリント及び石英の厚さ一筫際友び理論；製造 方法に於ける失敗 (a) 原翻配合に於ける，(b) フ リントの順備に於ける，(17)珪酸の烺焅の其性質に 及ぼす影響一珪酸の高比重形態と低比重形態；珪酸 の變化自在の形態; 违酸の三形態師ら石英; クリスト バライト及びトリデマイトの構造上の相違; 珪酸の 轉移の或る影響，（18）フリントの榐燒溫度の其素地

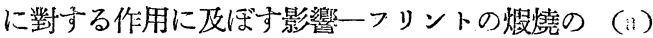
熱膨脹係数, (b) 比重, (c) スリップの重量, (d) 粉碎原料の粒子の大さ，(e) 素地の燒締り速度に及 ぼす影響，(19)素地の組成上の變化の翻の完全性に 對する影響一(a) 珪酸, (b) 長石又はコーニッシス トーン，(c) ムライト及び藍晶石，(d) ボールクレ 一又はチ+イナークレー，(e) 石灰及び白雲石，(f)

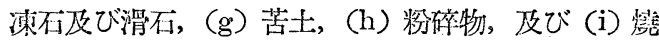
粉の割合の變化の影響; 素地の 3 成分郎ち粘土, 橴 劑; 及びフリント又は不英を變化させることの影響; 三角圖表; 分子式; 非磁器質素地; 磁器質素地; 冎 灰磁器，(20)釉の組成上の變化の其完全性に對する 影響一特質的データを得ることの困䧼なること；徹 底的の試驗をすれば洪大な仕事になる；珪酸; チタ ニヤ；ジルコニヤ；アルミナ(粘土として)；長石； コーニッシストーン; 矹酸; 着色酸化物; 酸化第二 鐵; ベース及び熔劑一曹達; 加里；リチヤ；石灰； 弗化カルシウム；骨灰；及び氷晶石； ストロチヤ； バライタ；ベリリヤ；マグネシヤ；酸化亞鉆；酸化 カドミウム；酸化錫；酸化鉛の影響;（21)䡬裂及び 涂離に對するゼーガーの法則ーH・ゼーガーの䉆した る重要なる研究; 批制; 診斷なしの菜、 二三の矯救 的處置一(a)素地(釉を一定にし)に對する變更，(b) 釉(素地一定)に對与る變更，(22)突發的笽裂一架發 


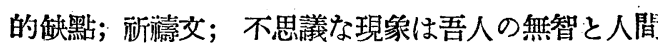
の誤り易きことに歸せられる；二三の例證； (23)施 釉タイルの使用中に於ける龜裂一I. 背部に用ひるセ メントの影響一乾懆氣中で凝結硬化した 水硬性セメ ントは惡く收縮する傾向があつて，床タイル又はタ イルの背部を締付けるーピンチ 效果一其篇に釉に歪 を起し龜裂を生ずる，(24)施釉タイルの使用中に於 ける鼠裂一II. タイルに對する水の影響一高筀蒸氣を 素地に作用せしめると數時間中に素地は 少し膨脹す るが; 釉は殆どヌは全く變化をしない，其結果龜裂 を生ずる。冷水でも長く作用させれば 同樣の結果を 起寸といら確證がある，（25)龜裂傾向の測定法一龜 裂に對する試驗一鼣裂に對する素地の抵抗性を測定 する方法は施釉素地中の歪を檢出する 方法である; 既に提唱されてるる方法; 浸漬試驗一I. 濕式試驗法 一加熱後沸騰水又は覧類溶液中に浸漬，一定時間例 へば 2 時間加熱した後に加熱蒸氣中に浸清し，次に 又二時間以上加熱して浸漬するといふ樣に次第々々 に加熱時間を長くして加熱浸漬を反覆して 龜裂發生 するに至つて止める；II. 乾式法一器物を適當な爐で 一定時間加熱して後冷處に出し此操作を 区覆して龜 裂の發生するに至つて止める，或は二度目には溫度 を $10^{\circ}$ 又は $20^{\circ}$ 昇げるといら樣に次第々に溫度を昇 げて行く方法もある。推獎。

内田

\section{IV. 耐 火材料}

\section{タロマイト及同類スピネルの反應膨脹測定}

(J. H. Chesters \& C. W. Parmelee, J. Amer. Ceram. Scc., 1935, 18, [3]94〜100) マグネシャとア ルミナ或は酸化クロム $\left(\mathrm{Cr}_{2} \mathrm{O}_{3}\right)$ との混合物中に生成 するスピネルの生成量は $2 \%$ 研酸を加へることに 依つて著しく坯加される。 $\mathrm{MgO}, \mathrm{Al}_{2} \mathrm{O}_{3}, \mathrm{Cr}_{2} \mathrm{O}_{3}$ の三 種の酸化物を $2 \mathrm{MgO}+\mathrm{Al}_{2} \mathrm{O}_{3}+\mathrm{Cr}_{2} \mathrm{O}_{3}$ の分子.比に混合 して加熱するときは，反應膨脹は前記二成分混合物 から得られる溫度より遥かに 低溫度に於て始まる。 此の生成物は綠色マグネシウムクロマイト及マグネ シャアルミネートより遥に大きく,クロマイトより 鲞に小さい lattice edge を持つて居る桃色のスピネ ルの混合物である樣に思われる。キューバ座のクロ マイトで作つた試驗體は $1300^{\circ} \mathrm{C}$ で收縮が始まる。 $1500^{\circ} \mathrm{C}$ に於ける 2 時間後の最後の收縮は $2.2 \%$ であ る。顯微鏡試驗に体ると蛙紋岩は毁に确子化して居 ることかわかる。粗きオーストリアのマグネサイト
$20 \%$ 或は電氣熔融マグネシヤの微粉未 $10 \%$ 加一 ることに体つて示される燒成收縮の均消 (Compensation) はフォルステライトに類似した複屈析性 鋌物の生成に依るものであると思われる。 $20 \%$ の アルミナを加へると $0.8 \%$ の燒成收縮が得られる。

茂木

マグネサイト煉瓦の性啠に及ばす粒子の大さ $の$ 影響 (G. Salmany \& P. Nemitz, Sprechsall, $1934,67 ; 717,729,745,759,775)$ 三種類の燒固した マグネサイトを以て, $\alpha=5 \sim 2 \mathrm{~mm}, \beta=2-0.25 \mathrm{~mm}$ 及 $\gamma=0.25 \sim 0 \mathrm{~mm}$ の粒子の大さを持つ種々の品貿の 素地を 9.10 種類作つた。此等の素地からハンドプレ ッス, 1.000 及 $750 \mathrm{~kg} / \mathrm{cm}^{2}$ の三種の壓力で長さ 40 $\mathrm{mm}$, 直徑 $27 \mathrm{~mm}$ の圓璹形供試體を作り, $1500^{\circ} \mathrm{C} て ゙$ 12 時間及 $1480^{\circ} \mathrm{C}$ で 8 時間致成して試驗を行つた非 常に細微な品質で試みられた場合，その性質は非常 なる變化を起す。供試體は普通の物理的性質に就い て試驗された。冷時破壤强度及 Shearing Strength は成形壓の增加及細末度の增加に比例して増加す る。荷重下の試驗に於ては成形避力を增加した場合 溃崩開始溫度が上昇する。台荷重下の軟化 溫度は成 形區力を高め, 適當な細未度のものを使用すること に依つて可成高められる。見掛氣孔率及熱膨脹は成 形婜力の增加及適度の細未度に依つて 減少される。 細微なものを最も多く含有する素地は必ずしも最低 氣孔率を與へない。溫度變化に對する抵抗力はべ クレーズの高膨脹係數に依つて決 定される, が佾更 に個々の粒子間母體の品質及固定性に依つて 決定さ れる。熱膨脹曲線は $20^{\circ} \mathrm{C}$ から $1800^{\circ} \mathrm{C}$ まで S字形 の曲線であつて, $1600^{\circ} \sim 1700^{\circ} \mathrm{C}$ の間で急に高まる。

茂木

\section{リカ含有量の異つそ數種雱火物の彈性率}

(R. A. Heindl \& W. I. Pendergast, Jour. Research Nat. Bur. Stand., 1934, 13, [6] 851 62) 48 $80 \%$ シカ含有の廣範圍の耐火粘土煉瓦の 10 種, 96 : $\%$ シリカ含有の珪石煉瓦 2 種, $16 \%$ シリカ含有の高 アルミナ湅瓦 1 種を選び此等各種 $\sigma$ 彈性率を測定し た。耐火粘土誎瓦は製造業者から受取つた時と，實 驗爐中で $1400^{\circ} \mathrm{C}$ で 5 時間再加熱した, 後とに就い て詮驗された，雒性率に對する而火度，氣孔率及其 の䋘織或は遊離シリカの構成等の影響も研究された 㛐瓦を 20, I1( $200,400,500$ 及 $600^{\circ} \mathrm{C}$ の各溫度 で試驗した結果, 彈性率は温度に依つて 非常に影響: 
を受けることが分つた。耐火粘 土煉瓦の 5 種類に對 しては彈性率は $20 \sim 500^{\circ} \mathrm{C}$ の間では漸次に增加し， $500^{\circ} \mathrm{C}$ と $600^{\circ} \mathrm{C}$ の間では寧ろ著しく急激に增加する .珪石䗲瓦の 2 種に對しては彈性率は $20^{\circ} \mathrm{C}$ から $175^{\circ} \mathrm{C}$ の範圍內では減少し, $175 \sim 600^{\circ} \mathrm{C}$ の間では增加する 低溫度範圍に於ける彈性率の減少は又高珪酸質の耐 火粘土䠅瓦にも認められる。高アルミナ煉瓦の彈性 率は $400^{\circ} \mathrm{C}$ まで一定であつて $600^{\circ} \mathrm{C}$ まで洹次に增 加する。室溫と $600^{\circ} \mathrm{C}$ の間では彈性率の㙛加百分率 とシリカ含有量との間には殆んど 直線的の關係があ る。份又若し此の煉瓦か殆儿ど同一耐火度のもので 西りシリカが熔融する 程高溫度に熱せられて居らな かつたならば, 線膨脹との間にも又直線的の關係が ある。2 種の珪石煉瓦及 3 種の高珪酸質耐火粘土煉 瓦を $100^{\circ} \mathrm{C}$ 以下゙の溫度間隔で試驗して行くと, 彈性 率はトリデマイトの轉化溫度附近で減少され, カリ ストバライトの轉化溫度附近で增加されることが分 る。然して何れの場合に於ても石英の轉化は增加を 示す。數種の試驗體を $800^{\circ} \mathrm{C}$ から比較的に徐々に冷 却して, その前後の唕性率を 試驗してみると, 此の 處理に依つて彈性率は低下されることが分る。これ に反してこの䒾驗體を $800^{\circ} \mathrm{C} \sim 1000^{\circ} \mathrm{C}$ から空氣急冷 を行ふと彈性率は耐火粘土湅瓦に於ては減少し，珠 石䗲瓦に於ては喤加し，高アルミナ酎瓦に於ては殆 んど全く變化を見ない。此の試驗に依つて得られた 值の數例を示すと，20，200 及 $600^{\circ} \mathrm{C}$ に於ける珪石 䗲瓦の彈性率は各々 $1,060,000 \mathrm{lb} / \mathrm{in}^{2}, 630.000 \mathrm{lb} / \mathrm{in}^{2}$ 及 $2,270.0001 \mathrm{~b} / \mathrm{in}^{2}$ である。 20 及 $600^{\circ} \mathrm{C}$ に於ける 80 \%アルミナ燥瓦の彈性率は备々 $2,700,000$ 及 $3,335,0$ $00 \mathrm{lb} / \mathrm{in}^{2}$ でむる。耐火粘土瑓瓦 の彈性率は 350,000 〜6,740,000 lb/in の範園である。茂木

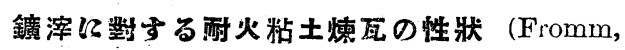
Ber. deut. keram. Ges., 1934, 15, [2], 49 65) 此の 試驗は些15 製造汽業者が作つた 50 種類の 耐火嫲瓦 に就いて鑛㳯に對する抵抗を测定せるるのである。 溫度變化に對する安定度の關係は餘り重 要でないと 䟷言される。 $1400^{\circ} \mathrm{C} に 2$ 時間の間鑪㴖に曝すと云 ふ一般に採用されて居る試驗は此のタイプの煉瓦に 對しては充分な差異を示さない。溫度上帠及試驗持 續期の增加に依つての夕充分な差異か欟られる。ア ルミナ含有と鉱滓作用に濧する性狀との間には何等 の關係子見出す事が出來なかつた。鏬漳 中の溶解度 は $1400^{\circ} \mathrm{C}$ に於ては氣孔率を增加すると共に僅加に
增加するが然し $1450^{\circ} \mathrm{C}$ に於ては鑛㳯 中の溶解度と 氣孔率との間には非常に大なる關係が存在する。耐 火物のたつた一個のタイプのものは例外であるが， これはその中の氣孔のタイプと分布に依つて居る。 與へられた任意の燃料に使用される最も適した耐火 物を如何に決定され得るかと云ら示されて居る。

茂木

粘土及耐火製品に對する石灰の融解及侵作

用 (V. Bodin, Céramique, 1934, 37，[555]，131-38) 種々の煉瓦及マグネサイトに對する石灰の影響が論 ぜられて居る。

茂 木

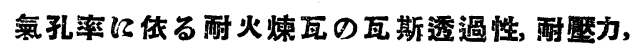
熱僡㽞率, 熱膨脹, 熱容量及破壤傾向 (H. Herbst, Fenerungs tochnik, 1934 22, [10] 115 116) アル ミナを含有し，約 $1600^{\circ} \mathrm{C}$ の耐火度を有する 揀瓦の 瓦斯透過性, 而篹力, 熱傳導度, $1000^{\circ} \mathrm{C}$ まの熱膨脤 熱容量及溫度の急變に對する 破壇傾问等に及济す氣 孔率の影響が曲線で示されて居る。瓦斯及コークス 製造に使用される煉瓦は可及的に瓦斯タイトでなく てはならない。最小の瓦斯透過性は氡孔率 が殆んど 零の時には得られ，20\%氣孔率に至るまで徐々に透 .過性を增加し，20３5\% 氣孔交では一增急激に墰加 する。氣孔率が零の時には熱德導率は最大であつて, 氣孔率 $20 \%$ に至るまで徐々に減小する。コークス 筧及熔融空の fire drafts に使用される䗲瓦は氮孔

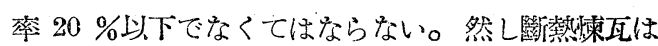
35〜 55\% の氣孔率を持たねばならない。氣孔率零の

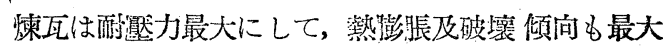
である。

茂木

蟯成结依るタルクの硬度 (V. H. Grigorovich, Mineral. Suir'e, 1934, 9,[5], 50〜57)耐火物とし てのタルクの使用は高溫度に於ける その耐火度增加 する硬菱及機械的强度に体るものである。著者は叞 燒溫度に体るタルクの硬度の變化を砟究した。得ら れた曲線を解析してみると種々の燒成溫度に体つて 起る變化の特性がわかる。宮際の結果はタルク煉瓦 の焅成は $1200 〜 1300^{\circ} \mathrm{C}$ の間で行はれできであると 云ふことを示した。タルク耐火物は $1300^{\circ} \mathrm{C}$ までの 溫度に使用することが最も良い。 茂林

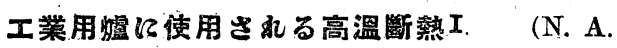

Humphrey, Blast Fur. Steel plant, 1934, 22, [12], 707〜 704) 㘂熱は熱の節約或は加 蓺裝置內に熱を保

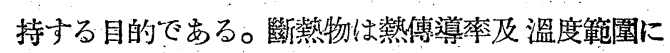


体つて分類される。熱㯖導率は溫表面の溫度或は溫 表面え, それを園む空氣との溫度差を基礎として溫 表面及冷表面間の平均溫度に依つて決定される。熱 傳導率の計算式が與へられて居る。茂木

解水酎火セメント (R. Dubrisay \& H. Lafuma, Céramique, 1934, 37, [557] 185〜90) 耐火性 用水セメントは主としてッェオライトと呼ばれる無 我モノカルシウムアルミネートから成立して居る該 物質は一定の含水監ではなくて固溶態である故に高 混度に於てもその結合作用を保持する。紌䅝なもの 依 $1400^{\circ} \mathrm{C}$ 以下では愹融されない。茂木

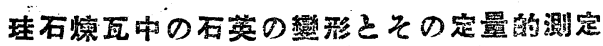

(G. V. Kukolev, N. M. Lozinskii \& E. I. TerMikaelyanz, Ulirain. Nauchno-Issled. Inst. Ogneuporov i Kislotouporv, 1934 [24] 4 51) 自動記錄裝 置を有する Chevenard の示差膨脹計を使用して恄 石煉瓦中の石英變形を定量的に测定することが出來 る。誤差の極限は $2 \%$ を超えない。試粼の製造法 が其の結果に相當影響を示す，平均膨脹係數による 訫算法は不適當である。珪石徚瓦中の石英を测定す るためには珪石湅瓦から棒を切取りて粉碎する。他 の變形を測定する場合は鑄型試料が使用される。玨 石料瓦は粉碎され，5\%の可溶玨酸監で成形しこれ を $800^{\circ} \mathrm{C}$ に整成する。加へられた可溶性理酸監の 補正は計算に依つてなされる。膨脹の平均値に住る 計算法は在來の方法である。若し得た曲線が充分な 精密度を持つ轉撸照を與へるならば計算は膨脹值の 紋溂値を使用して行ふことか出來る。茂木

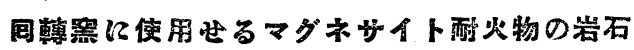

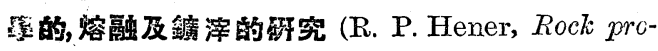
1934，37，[12] 42 46）岩石學的, 熔融及鏬㳯的解 究に依つて，烈しき便用の下に於けるポートラン ドセメント・ドロマイト及これと類似な覧基性物

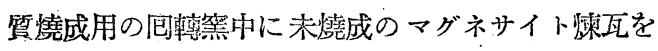

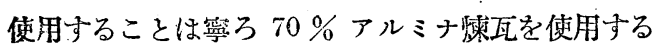
よりも良好であると云ふことが示された。マグネサ イト耐火物は不灰やマグネシア含有物の有害なる熔 融作用を被らない。末燒成のマグネサイト瑓瓦はポ ートランドセメント及ドロマイト熱塊の存在に於て

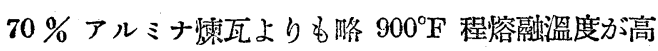
い。此の耐火度高き未燒成マグネサイトの內張をす ると最も酷烈なる作業狀態の下に於て，より高き作 栄溫度に堪え, 且つ耐火物の壽命子長く, 經費も低
廉になる。

茂木

石英シャモット混合物 (G. V. Kukolev \&. G. I Slabovskii, IJkrain Nauchno-Issted. Inst. Ogneuporov i Kislotouporov, 1934, No. 25, pp. 3 95) シリカーシャモット生產物は可成利盆を有して居 る, 郎ち該物質は特㣫の作業條件に埗之, 且つ單一 シャモット生產よりる優良品である。可塑性耐火粘 土，無水珪酸物質及シャモットはコークス弿，鉙鐵 顺䄪，キューポラ等の酷烈なる作業條件の下に伎用 される高級耐火物の原料として使用される。耐火粘 土は可塑性及結合力强く，且燒固溫度が低い。カオ リンは高級耐火物としては使用出來ない。器定形粒 子を最少限度に含む結晶石英或は結晶性クオルッっ イトはシリカ材料として使用される。燒成した耐火 性粘土及粉碎されたシャモット生產物は，若しも鑛 滓或は他の不純物を含有して居らないならばシャモ ットとして使用することが出來る。此の燒成された 蒵地のシリカ含有量が $75 \%$ より少くない㨾に石英 修料の量は $40 \%$ 以上使用しなければならない。シ ヤモ。トの量は $20 \%$ より少くてはならない。此の 燒成は 14 番で行われる。比載的低溫度用として微 粉の Soft cement quartzite を機械的强度を堶進す るために此の混合物に加へてもよい。茂木

解火物のスポーリング (Anon, World Pow:r, 1934, 21, [125]，261〜62) 物理的スポーリングは特 に水にて冷却する場合の樣に耐火物中に起る非常に 急激なる溫度公配に依るか, 或は急速なる溫度變化 に依つて起る。何れの場合に起る影響子龜裂が起る ために耐火物の物理的性質が不規則的に變ぜられ る。機械的スポーリングは素地の膨脹に依つて起る 局部的の應力に依る，そして可逆的熱膨脹がア一チ を膨起するためにアーチに起り勝ちである,そして その彎曲を變へる。これは眯瓦の inner ends が局 部的に匬縮を受けて低彎曲のアーチ中に抑提され る。

茂木

タルタ及ドューナイト匣錬素地 (R. T. Makhl, Keram. i. Stekls., 1934, 10, [10], 29〜32). タルク

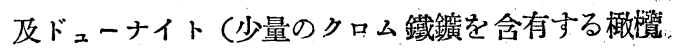
石）を含有する匣錸素地の試驗結果が述べられて居 る。タルク及ドューナイト素地の實驗數值を比較し てみると，總ての點に就いてタルク素地の方が，ド ユーナイト素地よりも優唀である事がわかつだ。兩 者其 $15 \%$ 含有の匣鉢素地㵊も良く, 强度高く， 
酎火度も充分である。實驗數値が表示及圖示されて 居る。

茂木

\section{マグネサイト䗲瓦の生座之岸酸監を原料之す}

る新煉瓦 (Z. Tabakov. \& V. Belovo 2 sky, Ogneuyorui，1934，2，[9]，8～13) マダネサイト工場の製 造法と生產制限が述べられて居る。マグネサイト鑬 を多量にするためにドロマイト首を加へて作つた， マグトサイトードロマイト鄁瓦はスポーリングに甚 完, 機械强度 $595 \mathrm{~kg} / \mathrm{cm}^{2}$, 容積重量 2.70 , 比重 3.72 , 見掛氣孔率 $18.9 \%$ ，吸水率 $7.0 \%$ ，荷重試驗に传る 變形溫度 $1500^{\circ} \mathrm{C}$ である。

茂木

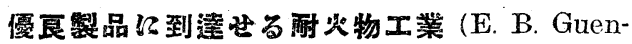
ther, Brick clay Rec., 1934, 85, [6], 206) 高耐火 度で堯固開始溫度高く且つスポーリング傾向低き超 耐火粘土湅瓦は特別に選擇せる適當の耐火性粘土或 はカオリンから作られる，(高アルミナ含有鑛物の少 量を加へる場合と加へない場合とを言わず)。高了ル ミナ煉瓦は $50,60,70$ 及 $80 \%$ アルミナを含有する ものが, 耐火物工箘上價值あるものである。珪藻土

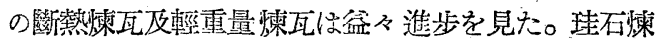

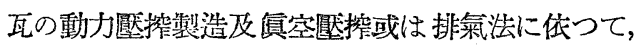
高熱容量で瓦斯, 鑛滓を透過しない緻密な媡瓦を作 ることが出來た。

茂木

タロム港を持り耐火セメント (Anon, Ind. Ci.imique, 1934, 21, [248]711) 此の生產物を “Adachrome”之呼び可塑性が大きく，收縮をなさず， 滑らかな表面を形成し，且つ容易に水分を吸收する 樣な耐火性斷熱闻瓦に應用することが出來る。この ものは常に顋金狀態に保つことが出來, 佾珪酸聽を 加へずに急速に硬化する。

茂木

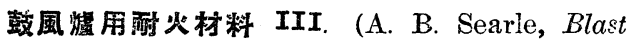
Fl:r. Steel Plarit, 1934, 22, [11],660～61) 鼓風爐の 頂上地帶に必要である强度は硬度に對して一層近い 關你がある。若しる㸮碎㪷驗を行はんとするなら ば, 楝瓦は使用されると殆んど同じ溫度で作られな ければならない。此の頂上地帶に使用する最す良好 な䠅瓦は, 摩隇及侵蝕に對して抵抗力が强い樣に充 分に緻密で且又細微な組織を有する低耐火度の耐火 粘土㛐瓦である。第二番目の地帶は瓦斯及融劑の化 學的作用があるだけに，填裝物に依る㗜隇作用が非 常に大である。然して高酎火度が必要ではあるが，

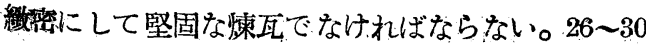
\%のアルミナを含有する耐火粘土熑瓦が通例十分な
耐火度のものである，そして若し徐々に良く燒成す れば填裝物に依る摩滅と侵蝕に堪え得る充分な硕度 と緻密のものが得られる。鼓風爐の最高溫度部であ る hea th 及 bash の部分に使用与る师酉は鏬涬及 熔融物に依る著しき透入を充分に防ぎ得る硬度と䋊 密を有し且つ非常な利火性のものでなければならな い 40 \%或はそれ以上のアルミナを含有して居る煉 瓦が現在使用されて居る。

茂木

\section{V. 建 築用品}

琴業品としての屋根础 (E. H. Berger, Ctramic Age, 1935, 25 [2]，49〜51） 屋根仯はアスファルト 莫の表面に使用する粒狀物で岩石，スレート，鑛㵏， 硝子, 磁器. タイル其他の物の破碎物である。筀業 としては 1921 年に初めて G. S. Finney が是を作 つたが，是は硬く，質緻密で，硝子化した着色粒で 吸水性なく又污れない。此物質は過剩の珠酸を用ひ

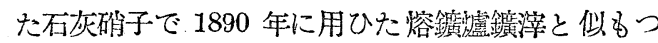
か奴ものである。色が良く出るので是はコンクリー トモザイクには非常に價值あるものであつたか，屋 根荤用として廣く用ひられるに至らなかつたのは， （1）破片は介颉狀で硙子らしきこと，(2) 形狀が角ば つてるること，(3) 透明で反射性高く，文從つてア スファルトと共に用ひた時色を失ふこと，(4) 取报 に碎け易きこと，アスファルトに對する附着力少な きこと，及び (6) 着色酸化物定多量に用ひ破碎に於 ける損失多き爰め製造費高きこと等である，其の後 Fisher は碎いた維色スレートの着色を行つた。 スレートに硫酸銅溶液老 飽和させ酸化炤で $1300^{\circ}$ $1400^{\circ} \mathrm{F}$ で燒いて酸化銅を作るのであるが，燒いた ものを次に溫かい內に硫酸第一鐵液中に落し再び烓 いて酸化銅と酸化鐵の化合物 (Cuferrite) を作るの である。此色は黄色から乖紫赤色迄變化してるる。 Fisher は上上の外スレートを鐵，クロム及び銅の 盬類で着色することを行つた。此際は $1100^{\circ} \mathrm{F}$ 及び $1800^{\circ} \mathrm{F}$ の燒成溫度を用ひた。後者ではスレートは 少し軟化物と結合してるる。次は珪酸鹽で被覆した 粒を作つた。珪酸曹達溶液に 群青又は他の顏料を㲘 濁したものでスレート䊀を濕しロータリーキルンで 此珪酸監を半熔せしめる。珠酸監を熔融してしまつ て橎となし夫を透明にする程溫度を上げてはいけな い。Fisher と同じ頃 Brown は多少氣孔性の耐火 性岩石の施釉を行つた。重クロム酸加里, 碿酸コン゙ 